\title{
Synthesis and bioactivity evaluation of metal ion-substitution biphasic calcium phosphate for bone defect reconstruction
}

\author{
Tae-Wan Kim, Dong-Hyun Kim, Hyeong-Ho Jin, Seung Ho Lee*, Hong-Chae Park and Seog-Young Yoon ${ }^{\dagger}$ \\ School of Materials Science Engineering, Pusan National University, Busan 609-735, Korea \\ *Echo Composite Materials Center, Korea Institute of Ceramic Engineering and Technology, Seoul 153-801, Korea \\ (Received October 8, 2012)
}

(Revised November 14, 2012)

(Accepted November 23, 2012)

\begin{abstract}
The co-precipitation technique has been applied to synthesize Biphasic Calcium Phosphate (BCP), Mg-BCP and Si-BCP. X-ray diffraction (XRD) and Fourier transformed infrared (FTIR) spectroscopy were used to characterize the structure of synthesized BCP, Mg-BCP and Si-BCP powders. The results have shown that BCP and substitution of magnesium and silicon in the calcium deficient apatites revealed the formation of biphasic mixtures of Hydroxyapatite (HAp)/ $\beta$-Tricalcium phosphate $\left(\beta\right.$-TCP) ratios after heating at $1000^{\circ} \mathrm{C}$. Ionic substituted $\mathrm{BCP}$ is able to develop a new apatite phase on the surface in contact with physiological fluids faster than BCP does. An MTT assay indicated that BCP, Mg-BCP, and Si-BCP powders had no cytotoxic effects on MG-63 cells, and that they have good biocompatibility.
\end{abstract}

Key words Biphasic calcium phosphate, Ionic-substituted, Magnesium, Silicon, Co-precipitation

\section{골결손부 재건을 위한 금속 이온 치환 이상인산칼슙 합성 및 생체 활성 평가}

김태완, 김동현, 진형호, 이승호*, 박홍채, 윤석영

부산대학교 재료공학부, 부산, 609-735

*한국세라믹기술원 에코복합소재센터, 서울, 153-801

(2012년 10월 8일 접수)

(2012년 11월 14일 심사완료)

(2012년 11월 23일 게재확정)

요 약 $\mathrm{BCP}, \mathrm{Mg}-\mathrm{BCP}, \mathrm{Si}-\mathrm{BCP}$ 분말을 공침법(co-precipitation process)을 이용하여 합성하였다. 제조된 분말을 X-선 회 절 분석(XRD), 적외선분광분석(FTIR)을 이용하여 특성을 분석하였다. $\mathrm{Ca} / \mathrm{P}$ 몰 비율이 1.602 인 칼슘 결손 아파타이트 공침 물을 제조하여 $1000^{\circ} \mathrm{C}$ 열처리 과정을 통하여 $\mathrm{HAp}$ 와 $\beta-\mathrm{TCP}$ 상이 혼재된 $\mathrm{BCP}, \mathrm{Mg}-\mathrm{BCP}, \mathrm{Si}-\mathrm{BCP}$ 을 합성할 수 있었다. 제조 된 분말의 생체활성 거동을 평가하기 위하여 Hanks' Balanced Salt Solution(HBSS)에 침적시켜 시간에 따라 형상의 변화 및 결정상을 분석한 결과, $\mathrm{BCP}$ 분말에 비하여 금속 이온이 치환된 $\mathrm{BCP}$ 분말에서 빠른 생체활성을 관찰할 수 있었다. MTT assay를 통한 세포 성장률 평가에서모든 분말에서 시간 경과에 따라 독성을 나타내지 않았으며, 세포의 활성이 증가 하였다.

\section{1. 서 론}

칼슘 인산염 기반의 재료들은 그들의 우수한 생체적합 성(biocompatibility), 생체활성(bioactivity) 및 골전도 (osteoconduction) 특성으로 인하여 치과 및 정형외과 영역 에 있어 골 재건을 위한 뼈 이식 대체재로서 많은 주목을

\footnotetext{
Corresponding author

Tel: +82-51-510-2487

Fax: +82-51-512-0528

E-mail: syy3@pusan.ac.kr
}

받아 오고 있다[1-4]. 특히, 가장 널리 사용되는 인산칼슘 계 세라믹은 수산화아파타이트 $\left[\mathrm{HAp}, \mathrm{Ca}_{10}\left(\mathrm{PO}_{4}\right)_{6}(\mathrm{OH})_{2}\right]$ 와 $\beta$-삼인산칼슘 $\left[\beta-\mathrm{TCP}, \mathrm{Ca}_{3}\left(\mathrm{PO}_{4}\right)_{2}\right]$ 이다. 이들 물질은 각각 의 생물학적 특성이 우수함에도 불구하고, 임상 시 생체 활성이 저하되는 단점이 존재한다. 기존의 in vitro, in vivo 관련 연구에서 $\mathrm{HAp}$ 는 체내 이식 후에 낮은 분해능 으로 인하여 최적의 골조직을 생성하기에는 한계를 나타 내는 것으로 알려져 있다 $[5,6]$. 이에 반해, $\beta-\mathrm{TCP}$ 는 생 체 내 체액에 노출되면 분해성으로 인하여 $\mathrm{Ca}^{2+}$ 과 $\mathrm{PO}_{4}^{3-}$ 이 빠르게 방출되어 골세포 증식을 위한 골격을 제공할 
수 없어, 임상 적용에 한계를 나타낸다고 보고되어 있다 $[7,8]$. 따라서 $\mathrm{HAp}$ 의 비분해성과 $\beta-\mathrm{TCP}$ 의 분해성을 적 절히 혼합하여 골전도성 유지 및 재료의 흡수성을 조절 한 이상인삼칼슘(Biphasic Calcium Phosphate; $\mathrm{BCP}$ )이 골이식 재료로서 제안되었다[9]. $\mathrm{BCP}$ 는 $\mathrm{HAp} / \mathrm{B}-\mathrm{TCP}$ 의 비율을 조절함으로써 생체활성과 생분해성을 조절할 수 있으나, 생체 내에서 최적의 골전도성을 나타내기 위한 $\mathrm{HAp} / \beta-\mathrm{TCP}$ 의 비율은 아직 명확히 제시되어 있지는 않 은 실정이다.

또한, 인산칼슘계 세라믹은 금속 이온이 쉽게 치환될 수 있는 구조를 가지고 있으며, 인체 이식 후 인산칼슘 계 세라믹 내에 치환된 이온 성분이 골 조직과의 작용에 의해 골 형성을 촉진한다고 보고되고 있다[10, 11]. 이러 한 이온이 첨가된 인산칼슘에서 이온의 종류 및 치환 농 도는 $\mathrm{wt} \%$ 에서 $\mathrm{ppm}$ 단위까지 다양하다[12, 13]. 이러한 이온의 종류나 치환되는 양에 따른 골 조직 내에서의 역 할에 대한 연구는 아직 충분하지 못한 실정이며, 이온 성분들이 골 조직 내에서 생체 내 화학적 거동에 영향을 미치는 것으로 받아들여지고 있다[14]. 이러한 이온들 중 $\mathrm{Si}$ 이온은 뼈 성장에 있어 생물학적으로 필수적인 요 소이며, $\mathrm{Si}$ 이온이 첨가된 인산칼슘계 생체재료는 생체 활성을 향상시키는 것으로 알려져 있다[15]. $\mathrm{Mg}$ 이온은 인체 내에서 조골세포(osteoblast)의 증식을 자극하여 뼈 형성 초기 단계에 중요한 역할을 제공하는 것으로 알려 져 있다[16, 17].

본 연구에서는 현재 치과용 골이식재로 사용되고 있는 프랑스 Biomatlante社의 $\mathrm{MBCP}$ 를 벤치마킹하여 생체활 성 소재인 $\mathrm{HAp}$ 와 분해성 소재인 $\beta$-TCP가 $60: 40$ 의 비 율로 혼합된 이상인산칼슘(Biphasic Calcium Phosphate; $\mathrm{BCP})$ 분말을 공침법을 이용하여 합성하였다. 또한, 이상 인산칼슘 구조 내에 $\mathrm{Mg}$ 이온과 $\mathrm{Si}$ 이온을 각각 치환하 여 이온 치환에 따른 $\mathrm{BCP}$ 의 물리적, 화학적 특성을 평 가하고, 제조된 $\mathrm{BCP}$ 분말의 생체재료로서의 적용가능성 을 평가하였다.

\section{2. 실험방법}

$\mathrm{BCP}$ 분말을 합성하기 위하여 $\mathrm{Ca}$ 공급원으로 $\mathrm{Ca}\left(\mathrm{NO}_{3}\right)_{2}$. $4 \mathrm{H}_{2} \mathrm{O}$ (Katayama chemical)를 사용하고, $\mathrm{P}$ 공급원으로 $\left(\mathrm{NH}_{4}\right)_{2} \mathrm{HPO}_{4}$ (Junsei chemical)를 사용하였다. $\mathrm{pH}$ 조절을 위하여 약염기성 물질인 $\mathrm{NH}_{3}$ (Junsei chemical)를 사용하 였다. $\mathrm{BCP}$ 조직 내에 $\mathrm{Mg}$ 및 $\mathrm{Si}$ 이온을 치환하기 위하 여 $\mathrm{Mg}\left(\mathrm{NO}_{3}\right)_{2} \cdot 6 \mathrm{H}_{2} \mathrm{O}$ (Junsei chemical)와 $\mathrm{Si}\left(\mathrm{OC}_{2} \mathrm{H}_{5}\right)_{4}$ (TEOS)(Sigma-Aldrich)를 출발물질로 사용하였다.

$\mathrm{BCP}$ 분말을 제조하기 위하여 $\mathrm{Ca} / \mathrm{P}$ 몰 비율을 1.602 로 고정하여 $\mathrm{Ca}\left(\mathrm{NO}_{3}\right)_{2} \cdot 4 \mathrm{H}_{2} \mathrm{O}$ 와 $\left(\mathrm{NH}_{4}\right)_{2} \mathrm{HPO}_{4}$ 을 각각 용
해시켜 수용액을 제조하였다. $\mathrm{Mg}-\mathrm{BCP}$ 분말을 제조하기 위하여 $(\mathrm{Ca}+\mathrm{Mg}) / \mathrm{P}$ 를 1.602 로 고정하여 $\mathrm{Mg}\left(\mathrm{NO}_{3}\right)_{2}$. $6 \mathrm{H}_{2} \mathrm{O}$ 를 $1.0 \mathrm{wt} \%$ 첨가하여 수용액을 제조한 후 제조된 용액에 $\mathrm{Ca}\left(\mathrm{NO}_{3}\right)_{2} \cdot 4 \mathrm{H}_{2} \mathrm{O}$ 와 $\left(\mathrm{NH}_{4}\right)_{2} \mathrm{HPO}_{4}$ 을 각각 첨가하 였다. $\mathrm{Si}-\mathrm{BCP}$ 분말을 제조하기 위하여 $\mathrm{Ca} /(\mathrm{P}+\mathrm{Si})$ 의 몰 비율을 1.602 로 고정하여 $\mathrm{TEOS}$ 를 $3 \mathrm{wt} \%$ 첨가하여 가 수분해 시키고, 가수분해 된 수용액에 $\mathrm{Ca}\left(\mathrm{NO}_{3}\right)_{2} \cdot 4 \mathrm{H}_{2} \mathrm{O}$ 와 $\left(\mathrm{NH}_{4}\right)_{2} \mathrm{HPO}_{4}$ 을 각각 첨가하였다. 각각의 제조된 수용 액에 $\mathrm{NH}_{3}$ 를 첨가하여 $\mathrm{pH}$ 를 11 로 조절하였다. 제조된 수용액을 2시간 동안 교반한 후 상온에서 24시간 동안 시효처리(Aging)하였다. 반응생성물의 여과 및 미 반응 물을 제거하기 위해 증류수로 수회 반복적으로 수세하고, 여분의 수분을 제거하기 위하여 $80^{\circ} \mathrm{C}$ 로 고정된 건조기에 서 24 시간 건조하였다. 건조된 분말을 분쇄하여, $1000^{\circ} \mathrm{C}$ 에서 2 시간동안 열처리 하였다. 열처리 후 분말을 400 mesh 체가름하였다.

제조된 $\mathrm{BCP}, \mathrm{Mg}-\mathrm{BCP}, \mathrm{Si}-\mathrm{BCP}$ 분말의 열처리 전 후 의 결정상 변화를 관찰하기 위해 $\mathrm{X}$-선 회절분석장치 (XRD, D/max-IIA, Rigaku, Japan)를 이용하여 분석하였 다. 측정조건은 $\mathrm{CuK \alpha}, 30 \mathrm{kV}, 25 \mathrm{~mA}$, scanning speed $1 \% \mathrm{~min}, 0.5 \mathrm{Slit}$ 계, 측정범위는 $25^{\circ} \sim 45^{\circ}(2 \theta)$ 이었다. 열처 리에 따른 탈수 축합 거동을 분석하기 위하여 주파수 $400-4000 \mathrm{~cm}^{-1}$ 범위에서 FT-IR(Nicolet Magna IR 560, USA) 측정하였다.

제조된 분말의 생체활성 거동을 비교 평가하기 위해 제조한 분말을 Hanks' Balanced Salt Solution(HBSS; Sigma-Aldrich)에서 1주, 2주, 3 주간 $36.5^{\circ} \mathrm{C}$ 의 인큐베 이터에서 침적 테스트하였으며, 일정한 이온 농도를 유 지하기 위하여 $\mathrm{HBSS}$ 를 2일마다 교환해주었다. HBSS 침적 후의 시간에 따른 표면 형상의 변화 및 표면의 결정성 변화를 XRD 및 $\mathrm{SEM}$ 을 통하여 관찰하였다. 합성한 분말의 세포와의 친화력을 비교 평가하기 위하 여 Human osteosarcoma cell line인 MG-63을 이용 하여 MTT assay를 실시하였다. MTT assay는 cell을 penicillin $(100 \mathrm{units} / \mathrm{m} l)$, streptomycin $(100 \mu \mathrm{g} / \mathrm{m} l)$ solution 과 $10 \%$ 우태아 혈청(fetal bovine serum; FBS, Gibco) 이 포함된 Dulbeco's Modified Eagle's Medium(DMEM, Gibco, USA) 배지를 사용하여 $5 \% \mathrm{CO}_{2}, 37^{\circ} \mathrm{C}$ 배양 기에서 배양시켜 사용하였다. 우선 24 well에 MG-63 $1 \times 10^{4}$ 개를 분주하고, 24 시간 뒤에 새 배지로 교체 후 시료를 $1 \mathrm{mg} / \mathrm{m}$ 로 처리하였다. 3-(4,5-dimethylthiozol-2-ly)-2,5-diphebyltetrazolium bromide(MTT) $(5 \mathrm{mg} /$ $\mathrm{m} l$ )을 각 well에 처리하여 4시간 배양한 후 형성된 insoluble formazan을 DMSO(dimethyl sulfoxide)에 녹이 고 ELISA(enzyme-linked immunosorbent assay) reader (Wallac 1420, USA)를 통해 $570 \mathrm{~nm}$ 에서 흡광도를 측정 하였다. 


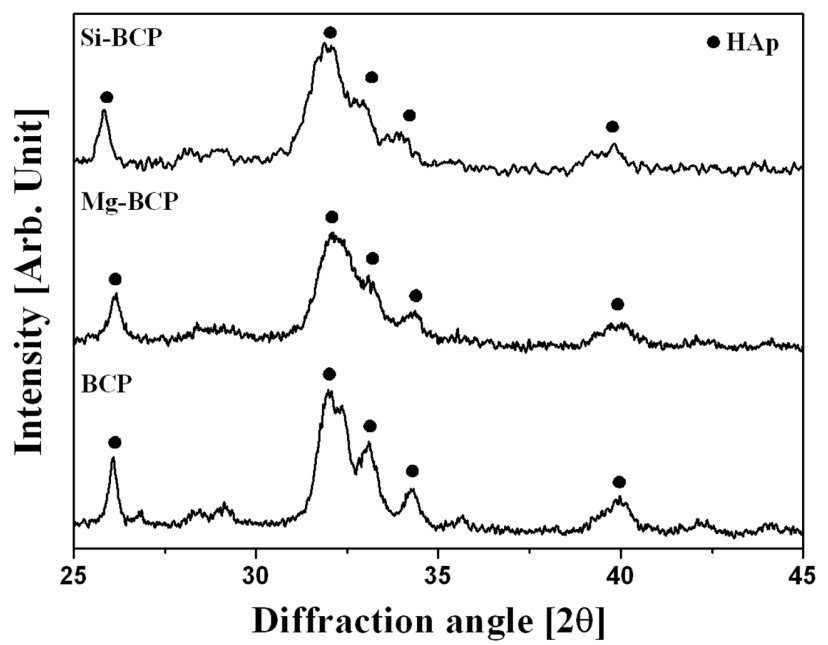

Fig. 1. XRD patterns of the as-synthesized BCP, Mg-BCP and Si-BCP powders.

\section{3. 결과 및 고찰}

$\mathrm{BCP}$ 및 이온이 치환된 $\mathrm{BCP}$ 공침 분말의 $\mathrm{X}$-선 회절 패턴 결과를 Fig. 1에 나타내었다. 이온 치환 유무에 관 계없이 모든 샘플의 공침 분말은 저결정성 $\mathrm{HAp}$ 회절패 턴을 나타내었다. 상대적으로 이온이 치환된 $\mathrm{BCP}$ 분말 의 경우 $\mathrm{BCP}$ 분말에 비해 이온의 치환에 따른 영향으 로 결정성이 감소하는 경향을 나타내었다. 이러한 결과 는 이전의 연구 결과들에서 습식법을 이용한 아파타이트 합성 시 전형적으로 나타나는 저결정 패턴이며[18], 공 침법에 의한 $\mathrm{HAp}$ 분말 합성의 경우에 $\mathrm{Ca} / \mathrm{P}$ 몰비율이 1.67 보다 적어도 공침분말은 $\mathrm{HAp}$ 회절 패턴을 나타낸 다는 앞선 연구결과와 일치한다[19]. 일반적으로 칼슘 결손 아파타이트 $\left[\mathrm{d}-\mathrm{HAp}, \mathrm{Ca}_{10-\mathrm{x}}\left(\mathrm{HPO}_{4}\right)_{\mathrm{x}}\left(\mathrm{PO}_{4}\right)_{6-\mathrm{x}}(\mathrm{OH})_{2-\mathrm{x}}\right.$ ] 의 경우 $\mathrm{Ca} / \mathrm{P}$ 몰 비율이 1.5 에서 1.67 의 다양한 조성의 $\mathrm{HAp}$ 와 $\beta-\mathrm{TCP}$ 의 혼합상을 형성시킬 수 있으며(Eq. 1) 열처리 과정을 통하여 $700^{\circ} \mathrm{C}$ 부근부터 이상(biphasic) 조직이 나타난다[20, 21].

$$
\begin{aligned}
& \mathrm{Ca}_{10-\mathrm{x}}\left(\mathrm{HPO}_{4}\right)_{\mathrm{x}}\left(\mathrm{PO}_{4}\right)_{6-\mathrm{x}}(\mathrm{OH})_{2-\mathrm{x}} \\
& \quad \rightarrow(1-\mathrm{x}) \mathrm{Ca}_{10}\left(\mathrm{PO}_{4}\right)_{6}(\mathrm{OH})_{2} \\
& \quad+3 \mathrm{xCa}_{3}\left(\mathrm{PO}_{4}\right)_{2}+(\mathrm{OH})_{2-\mathrm{x}}+\mathrm{xH}_{2} \mathrm{O}
\end{aligned}
$$

$\mathrm{Si}-\mathrm{BCP}$ 공침 분말의 경우 $\mathrm{Mg}-\mathrm{BCP}$ 분말과 $\mathrm{BCP}$ 분말에 비하여 전체적으로 저결정성 $\mathrm{HAp}$ 의 주피크가 저각으로 이동하였는데, 이는 $\mathrm{Si}$ 이온의 경우 양이온인 $\mathrm{Ca}$ 이온과 의 치환 거동이 아닌 음이온인 $\mathrm{PO}_{4}$ 이온과의 치환거동 때문인 것으로 사료되어진다.

공침분말을 $1000^{\circ} \mathrm{C}$ 열처리한 후 생성된 $\mathrm{BCP}, \mathrm{Mg}$ $\mathrm{BCP}, \mathrm{Si}-\mathrm{BCP}$ 분말의 $\mathrm{X}$-선 회절 패턴을 $\mathrm{Fig}$. 2에 나타 내었다. 각각의 분말에서 $\beta$-TCP의 (0210)면(JCPDS \#090169)과 HAp의 (211)면(JCPDS \#74-0566)이 나타남을

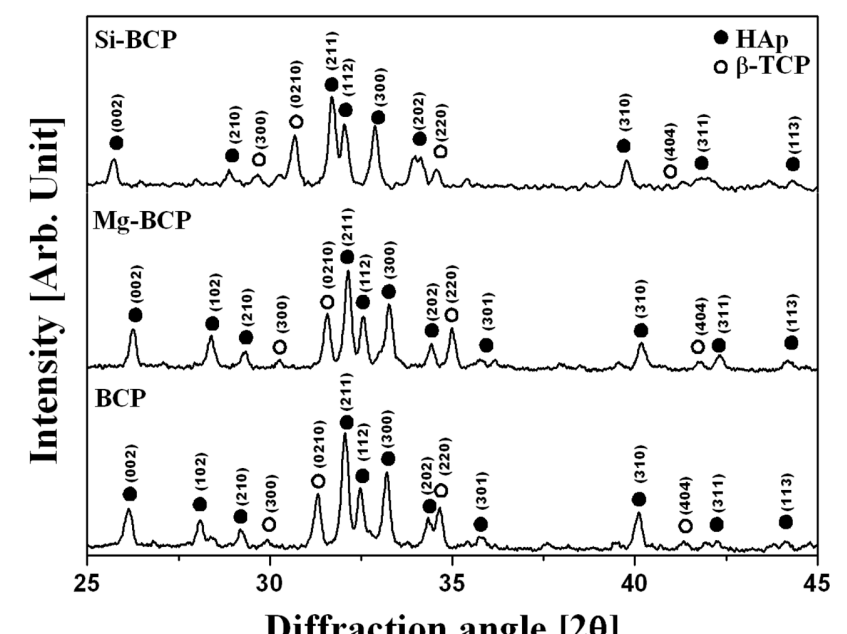

Fig. 2. XRD patterns of the calcined BCP, Mg-BCP and Si-BCP powders.

관찰할 수 있었다. 측정된 $\mathrm{X}$-선 회절패턴 결과를 $\mathrm{BCP}$ 분말의 적분강도 값을 (Eq. 2)에 대입하여 부피 분율 (RIR: Relative Intensity Ratio)을 계산한 결과 본 연구 에서 얻고자 하는 $\mathrm{HAp} / \beta-\mathrm{TCP}=60: 40$ 의 $\mathrm{BCP}$ 분말을 얻을 수 있었다.

$$
\mathrm{RIR}=\frac{\mathrm{I}_{\beta-\mathrm{TCP}}}{\mathrm{I}_{\mathrm{HAp}}+\mathrm{I}_{\beta-\mathrm{TCP}}}
$$

$\mathrm{Mg}$ 이온이 치환된 $\mathrm{BCP}$ 분말의 경우 $\beta-\mathrm{TCP}$ 의 (0210)면 의 회절패턴이 $\mathrm{Mg}$ 이온의 치환으로 인하여 이동하는 현 상을 관찰 할 수 있다. 이는 $\mathrm{Mg}$ 이온의 치환이 $\beta$-TCP에 서 우선적으로 이루어지고, $\mathrm{Ca}$ 의 이온반경이 $0.99 \AA$ 이 며, $\mathrm{Mg}$ 의 이온반경이 0.65 으로 이들 이온의 이온반 경의 차이에 의하여 $\beta-\mathrm{TCP}$ 의 주피크의 $2 \theta$ 가 이동하는 것으로 사료되어진다 $[22,23]$. 측정된 $\mathrm{X}$-선 회절패턴 결 과를 토대로 적분강도 값을 (Eq. 2)에 대입하여 부피 분 율을 계산한 결과 $\mathrm{Mg}$ 가 치환된 경우 이론적인 $\mathrm{HAp} / \beta$ $\mathrm{TCP}=60: 40$ 의 비율에서 벗어나 $\mathrm{Mg}$ 이온의 치환으로 인하여 $\beta-\mathrm{TCP}$ 의 양이 증가하는 경향을 나타내었다. 이 는 $\mathrm{HAp}$ 에 $\mathrm{Mg}$ 이온이 치환된 메커니즘을 통하여 설명 이 가능할 것으로 판단되어진다[24].

$$
\begin{aligned}
\mathrm{Ca}_{10-\mathrm{x}}\left(\mathrm{Mg}_{2} \mathrm{P}_{2} \mathrm{O}_{7}\right)_{\mathrm{x} / 2}\left(\mathrm{PO}_{4}\right)_{6-\mathrm{x}}(\mathrm{OH})_{2-\mathrm{x}}+\mathrm{x} / 2 \mathrm{H}_{2} \mathrm{O} \\
\quad \rightarrow(1-\mathrm{x}) \mathrm{Ca}_{10}\left(\mathrm{PO}_{4}\right)_{6}(\mathrm{OH})_{2} \\
+3 \mathrm{x}\left(\mathrm{CaMg}_{2 \mathrm{x} / 9}\right)_{3}\left(\mathrm{PO}_{4}\right)_{2}+\mathrm{xH}_{2} \mathrm{O}
\end{aligned}
$$

(Eq. 3)에 의하면, $\mathrm{Mg}$ 이온이 $\mathrm{HAp}$ 에 치환되면 $\mathrm{Mg}$ 이온의 영향으로 $\mathrm{HAp}$ 가 아닌 $\beta$-TCP에서 먼저 치환이 일어나게 된다. $\mathrm{Mg}^{2+}$ 의 이온반경이 $\mathrm{Ca}^{2+}$ 의 이온반경에 비하여 작기 때문에 이온화 에너지에 의한 결합력이 증 가한다. 이로 인해 이온결합인 $\mathrm{Mg}^{2+}$ 양이온과 $\mathrm{PO}_{4}^{3-}$ 음 이온의 결합력이 증가하여 $\mathrm{OH}^{-}$결합을 상대적으로 배제 
하여 마그네슘의 첨가량이 증가할수록 $\beta-\mathrm{TCP}$ 의 비율이 증가하는 것으로 판단되어진다.

$\mathrm{Si}$ 이온이 치환된 $\mathrm{BCP}$ 분말의 경우 $\mathrm{Si}$ 이온의 치환에 의해 $\mathrm{HAp}$ 의 (211)면과 $\beta-\mathrm{TCP}$ 의 (0210)면의 회절강도 가 감소하는 경향을 나타내는데, 이는 $\mathrm{Si}$ 치환으로 인하 여 상대적으로 인산염 결손이 나타나서 생기는 현상으로 사료되어진다. 또한, $\beta-\mathrm{TCP}$ 의 (0210)면의 회절패턴이 $\mathrm{Si}$ 가 치환됨으로써 이동하는 현상을 관찰할 수 있다. 이는 $\mathrm{Si}-\mathrm{O}$ 간의 원자간 거리가 $1.66 \AA$ 이며, $\mathrm{P}-\mathrm{O}$ 간의 원자간 거리가 $1.57 \AA$ 으로 결합 원자간 거리의 차이로 인하여 나타나는 현상으로 사료되어진다. 인산염의 대체로 $\mathrm{Si}$ 이온이 치환된 다른 연구결과에 의하면 $\mathrm{Si}$ 이온 치환에 따라 원자간 거리 차이로 인하여 단위격자의 부피가 증 가하여 회절패턴이 이동하는 현상이 나타나고, 아파타이 트 구조의 안정성을 감소시켜 생체활성을 높일 수 있다 고 한다[23]. 또한, 측정된 $\mathrm{X}$-선 회절패턴 결과를 토대 로 적분강도 값을 $(\mathrm{Eq} .2)$ 에 대입하여 부피 분율을 계산 한 결과 $\mathrm{Si}$ 이온이 치환된 경우 이론적인 $\mathrm{HAp} / \beta-\mathrm{TCP}$ $=60: 40$ 의 비율과 정확히 일치하는 결과를 얻지 못하였 다. 이러한 경향은 HAp에 인산염을 대신하여 규산염이 치환된 메커니즘을 통하여 설명이 가능할 것으로 판단되 어진다[15].

$$
\mathrm{V}_{\mathrm{Ca}}+\mathrm{PO}_{4}^{3-}+\mathrm{OH}^{-} \leftrightarrow \mathrm{Ca}^{2+}+\mathrm{SiO}_{4}^{4-}+\mathrm{V}_{\mathrm{O}}^{2-}
$$

$\left(\mathrm{V}_{\mathrm{Ca}}\right.$ : indicates a vacancy in the calcium site)

(Eq. 4)에 의하며, 규산염의 치환은 $\mathrm{Ca}^{2+}$ 와 $\mathrm{O}^{2-}$ 의 양을 증가시켜 이온의 불균형을 일으켜, 이론적인 결과 값과 실험에 의해 측정된 결과 값에 차이를 보인다. 이러한 결과는 $\mathrm{BCP}$ 에 $\mathrm{Si}$ 이온이 치환된 다른 연구결과와 일치 한다 [25, 26].

$\mathrm{BCP}, \mathrm{Mg}-\mathrm{BCP}, \mathrm{Si}-\mathrm{BCP}$ 공침분말의 FTIR 결과를 Fig.

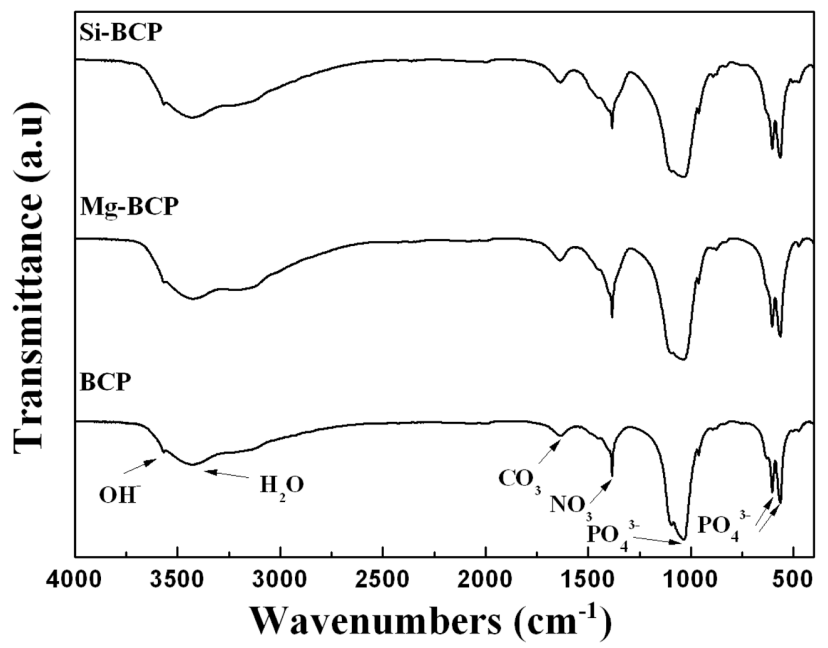

Fig. 3. FTIR spectra of as-synthesized $\mathrm{BCP}, \mathrm{Mg}-\mathrm{BCP}$ and Si-BCP powders.

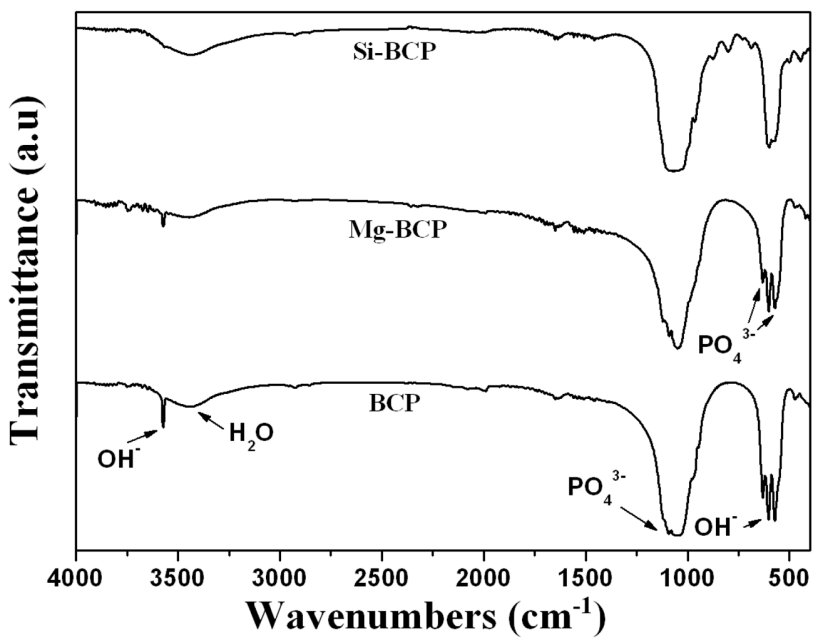

Fig. 4. FTIR spectra of calcined $\mathrm{BCP}, \mathrm{Mg}-\mathrm{BCP}$ and Si-BCP powders.

3에 나타내었다. 모든 공침 분말에서 574, 603 그리고 $1020 \sim 1120 \mathrm{~cm}^{-1}$ 의 진동모드에서 $\mathrm{PO}_{4}$ 그룹과 603,3570 $\mathrm{cm}^{-1}$ 의 진동모드에서 $\mathrm{OH}^{-}$그룹의 $\mathrm{HAp}$ 상을 관찰할 수 있었다[27]. 이는 앞에서 언급한 $\mathrm{X}$-서 회절분석에서 얻 어진 저결정성 $\mathrm{HAp}$ 를 나타내는 것을 뒷받침 하는 결과 라고 판단되어진다. 또한, $3300 ~ 3600 \mathrm{~cm}^{-1}$ 의 진동모드는 수분흡착에 의한 것이며, 1660 과 $1385 \mathrm{~cm}^{-1}$ 의 진동모드 는 공침분말에 잔류하는 탄산염과 질산염의 존재로 사료 되어진다.

Fig. 4의 열처리 후 FTIR의 스펙트럼은 모든 $\mathrm{BCP}$ 분 말에서 전체적으로 $\mathrm{PO}_{4}^{3-}$ 와 $\mathrm{OH}^{-}$그룹에 해당하는 632 와 $3570 \mathrm{~cm}^{-1}$ 의 진동모드를 관찰할 수 있었다. 이는 열처리 후 $\mathrm{BCP}$ 분말이 $\mathrm{HAp}$ 와 $\beta$ - TCP의 혼재된 상이 나타나는 $\mathrm{X}$-선 회절 패턴 결과를 뒷받침 해주는 결과로 판단되어 진다. $\mathrm{Mg}$ 이온이 치환된 경우 $\mathrm{OH}^{-}$그룹의 진동모드가 감소하고, $\mathrm{PO}_{4}^{3-}$ 의 진동모드의 강도가 약해지는 경향을 나타내었다. 이러한 경향은 습식공정을 이용한 인산칼슘 합성 시 $\mathrm{Mg}$ 이온의 치환에 따라 $\mathrm{HPO}_{4}^{2-}$ 의 증가로 나타 나는 현상으로 판단되어진다. $\mathrm{Si}$ 이온이 치환된 $\mathrm{BCP}$ 분 말 역시 $\mathrm{OH}^{-}$그룹의 진동모드가 감소하는 경향을 나타 내었다. 이러한 현상은 인산칼슘 구조에 $\mathrm{Si}$ 가 치환되면 $\mathrm{PO}_{4}^{3-}$ 가 $\mathrm{SiO}_{4}^{4-}$ 로 전환되어 나타나는 결과로 다음의 메커 니즘을 통하여 $\mathrm{OH}^{-}$그룹의 감소를 설명할 수 있을 것으 로 사료되어진다.

$$
\mathrm{PO}_{4}^{3-}+\mathrm{OH}^{-} \leftrightarrow \mathrm{SiO}_{4}^{4-}+\mathrm{V}_{\mathrm{OH}}
$$

$\left(\mathrm{V}_{\mathrm{OH}}\right.$ : indicates a vacancy in the hydroxyl site)

$\mathrm{Si}$ 이온이 치환됨으로써 $\mathrm{OH}^{-}$그룹의 감소되는 현상은 Eq. 5에서와 같이 $\mathrm{PO}_{4}^{3-}$ 와 $\mathrm{OH}^{-}$의 결합에 의해 $\mathrm{V}_{\mathrm{OH}}$ 가 증 가하고, $\mathrm{SiO}_{4}^{4-}$ 가 생성되기 때문이다. 생성되는 $\mathrm{SiO}_{4}^{4-}$ 이 온은 $\mathrm{SiO}_{4}$ 사면체 구조에서 기인하며, 이러한 $\mathrm{SiO}_{4}^{4-}$ 가 


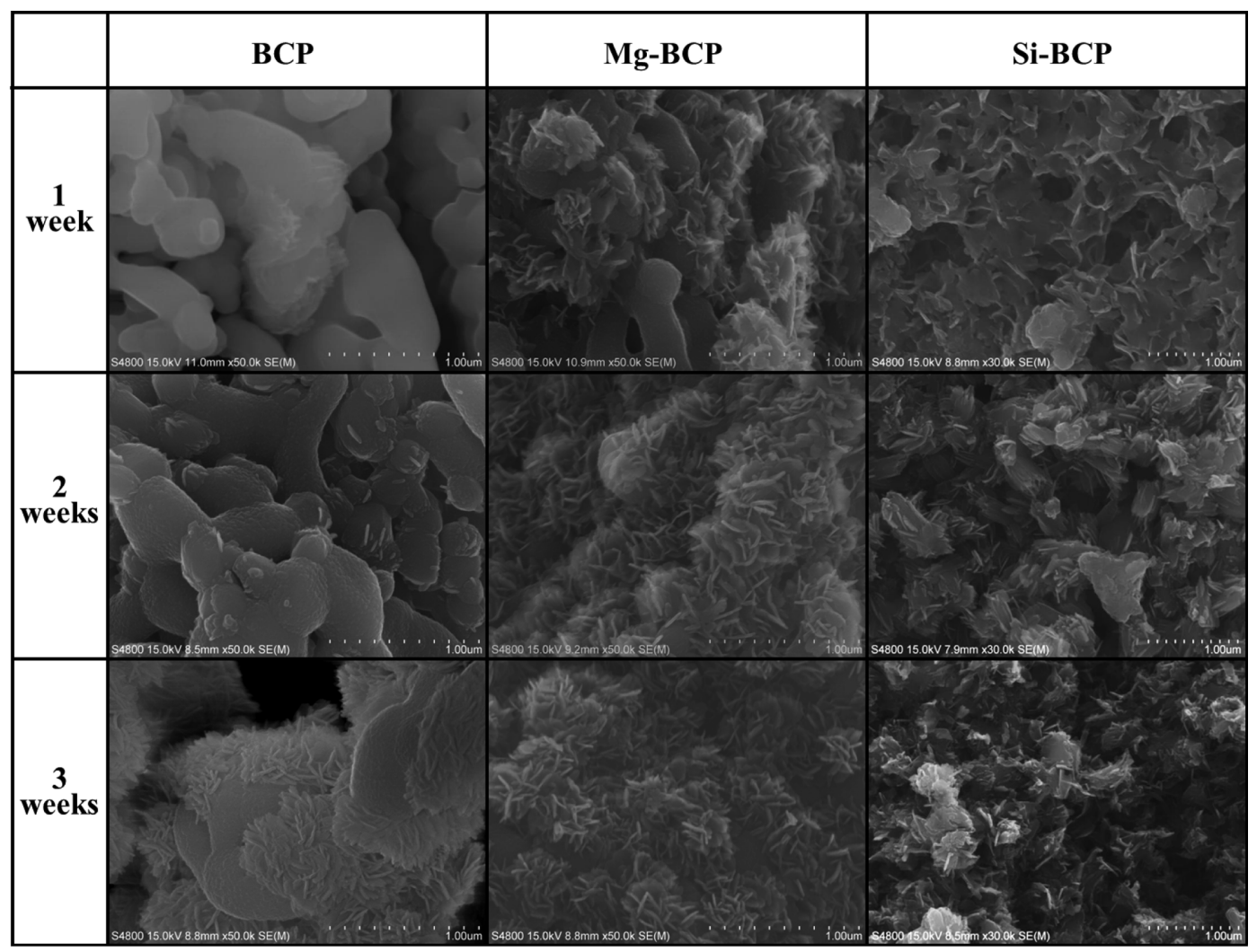

Fig. 5. SEM micrographs of calcined BCP, Mg-BCP and Si-BCP powders after immersion in HBSS for 1, 2 and 3 weeks.

세라믹재료에 도입되면 표면의 전하를 감소시키게 되어 생물학적인 반응에 영향을 주는 것으로 사료되어진다 [25].

제조된 $\mathrm{BCP}, \mathrm{Mg}-\mathrm{BCP}, \mathrm{Si}-\mathrm{BCP}$ 분말의 생체 적용 가 능성을 평가하기 위하여 의사체액의 일종인 Hanks' Balanced Salt Solution(HBSS)에 침적 시킨 후 시간에 따른 표면의 형상 변화를 관찰한 결과를 Fig. 5에 나타 내었다. 침적 1 주 후 $\mathrm{BCP}$ 분말과 비교하여 $\mathrm{Mg}-\mathrm{BCP}$, $\mathrm{Si}-\mathrm{BCP}$ 분말의 표면에서는 활성이 일어나 휘스커 타입 의 입자가 생성됨을 관찰할 수 있었다. $\mathrm{BCP}$ 분말의 경 우 침적 2주 후부터 표면에 활성이 나타나 휘스커 타입 의 입자가 생성되며, 3 주 후 표면 전체로 확산이 일어나 는 경향을 나타내었다. $\mathrm{Mg}-\mathrm{BCP}$ 분말의 경우 침적 3 주 후 표면에 새로 생성된 휘스커 타입의 입자가 커지는 경 향을 나타내며, $\mathrm{Si}-\mathrm{BCP}$ 분말은 침적 3 주 후 표면에 생 성된 입자가 판상의 형태에 가까워지는 경향을 나타내었 다. Fig. 6의 침적 3주 후 분말의 X-선 회절 패턴의 결 과를 관찰하면, $\mathrm{BCP}$ 분말에 비하여 $\mathrm{Mg}-\mathrm{BCP}$ 분말의 경 우 상대적으로 $\beta-\mathrm{TCP}$ 와 $\mathrm{HAp}$ 의 피크가 감소하는 경향 을 나타내는데 이는 $\mathrm{Mg}$ 이온 자체의 우수한 생체활성 과 $\mathrm{Mg}$ 이온이 인산칼슘 내에서 $\mathrm{Ca}$ 이온과의 치환 거동 에 의해 생체활성을 증가시킨 것이며 $\beta-\mathrm{TCP}$ 의 분해에 의한 결과는 아닌 것으로 사료된다. $\mathrm{Si}-\mathrm{BCP}$ 분말의 경

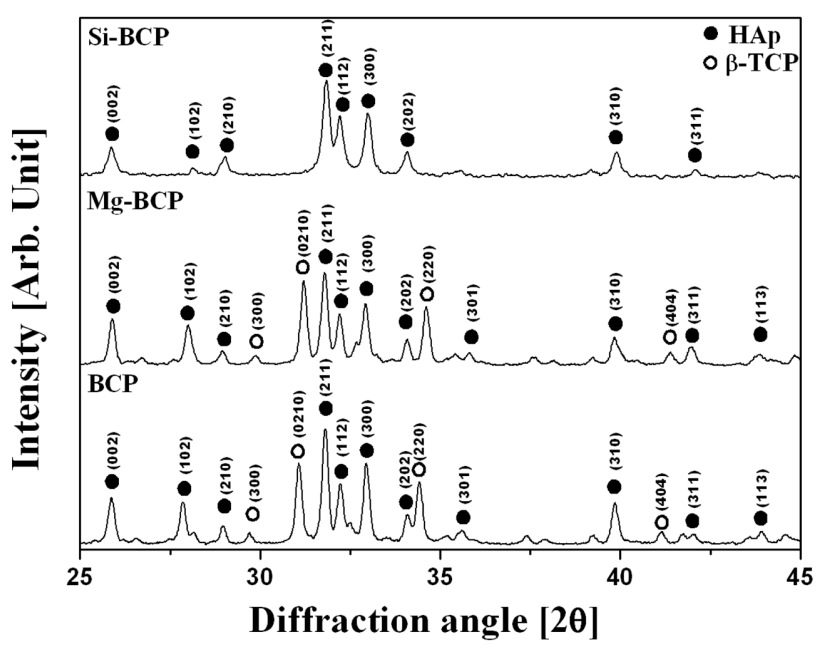

Fig. 6. XRD patterns of $\mathrm{BCP}, \mathrm{Mg}-\mathrm{BCP}$ and Si-BCP powders after immersion in HBSS for 3 weeks.

우 침적 3 주 후 두 분말과 달리 $\beta-\mathrm{TCP}$ 피크는 사라지 고 $\mathrm{HAp}$ 피크만 남아있는 현상을 관찰할 수 있다. 이는 $\mathrm{Si}$ 이온이 인산칼슘 조직에 치환될 경우 앞서 설명한 바 와 같이 구조적 안정성을 감소시켜 $\beta-\mathrm{TCP}$ 의 빠른 분해 를 일으킨 것으로 사료되어진다[28, 29]. $\mathrm{BCP}$ 분말의 경우 이온이 치환된 $\mathrm{BCP}$ 분말에 비하여 의사체액 내에 서의 활성화 속도는 늦으나 생체활성을 나타내는데 이는 


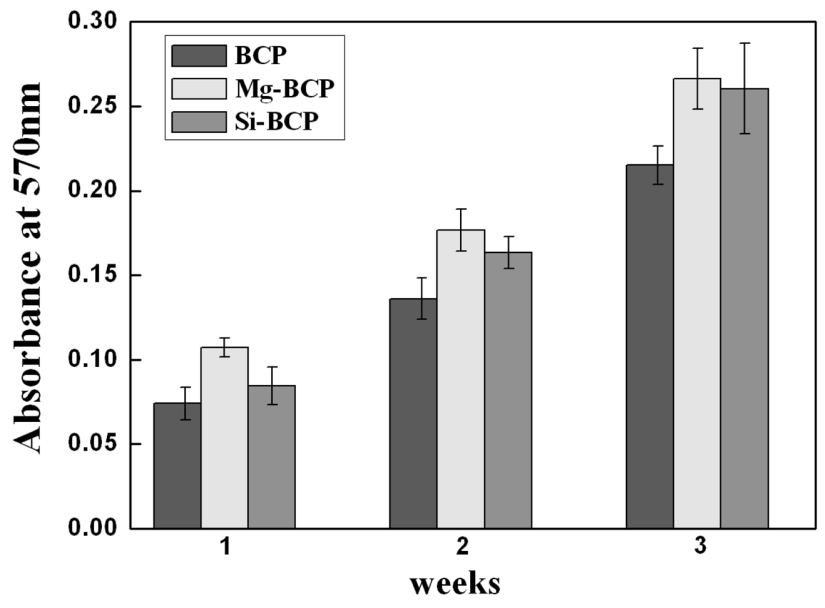

Fig. 7. Effect of $\mathrm{BCP}, \mathrm{Mg}-\mathrm{BCP}$ and $\mathrm{Si}-\mathrm{BCP}$ powders on cell viability in human osteosarcoma MG-63 cells.

앞선 연구결과의 의사체액 내에서의 이온 농도 변화에 따르면, 침적 시간이 길어짐에 따라 $\mathrm{Ca}^{2+}$ 와 $\mathrm{PO}_{4}^{3-}$ 의 이온 농도가 감소하여 분말의 표면에서 $\mathrm{Ca}^{2+}$ 와 $\mathrm{PO}_{4}^{3-}$ 이온이 용출되어 인산칼슘염의 핵생성을 촉진시키는 것으로 판 단되어진다[30-32].

Fig. 7은 제조된 $\mathrm{BCP}$ 분말의 MTT assay 결과이다. $\mathrm{DMEM}$ 배지에 $\mathrm{BCP}, \mathrm{Mg}-\mathrm{BCP}, \mathrm{Si}-\mathrm{BCP}$ 분말을 첨가하 여 MG-63 세포의 성장률을 비교하여 ELISA(EnzymeLinked Immuno Sorbent Assay) 검출기(Wallac 1420, USA)를 통해 $570 \mathrm{~nm}$ 에서 흡광도를 측정한 결과를 나타 내었다. 1 주 후 $\mathrm{BCP}$ 분말에 비하여 이온이 첨가된 $\mathrm{BCP}$ 분말의 세포의 성장률이 높으며, 또한 $\mathrm{Mg}-\mathrm{BCP}$ 분 말의 의 경우 $\mathrm{Si}-\mathrm{BCP}$ 분말의 세포 성장률과 비교하여 높은 것으로 나타나며, 세포 실험 3 주 후 두 샘플의 차 이는 상대적으로 감소하는 경향을 나타내었다. 이는 $\mathrm{HBSS}$ 침적 후 $\mathrm{BCP}$ 표면의 생체활성 결과에서와 같이, $\mathrm{BCP}$ 에 비하여 이온이 치환된 $\mathrm{BCP}$ 분말이 침적 후 저 결정성 휘스커 타입의 HAp 생성이 빠르게 일어나 생체 활성이 우수해지는 것과 같은 결과로 사료되어진다. $\mathrm{BCP}$ 분말 또한 앞선 연구결과의 대조군에 비하여 세포 활성이 우수함을 나타내었다[32].

\section{4. 결 론}

본 연구에서는 생체활성 소재인 $\mathrm{HAp}$ 와 분해성 소재 인 $\beta$-TCP가 이상(biphasic)으로 존재하는 $\mathrm{BCP}$ 분말과 $\mathrm{BCP}$ 조직 내에 생체 활성을 향상 시키는 $\mathrm{Mg}$ 이온과, $\mathrm{Si}$ 이온을 각각 치환하여 $\mathrm{Si}-\mathrm{BCP}, \mathrm{Mg}-\mathrm{BCP}$ 분말을 공침 법을 이용하여 합성하였다. 합성된 분말의 $\mathrm{X}$-선 회절 분 석 및 적외선 분광분석을 실시하고, HBSS에 침적시켜 시간에 따른 $\mathrm{BCP}$ 분말의 표면 활성 및 결정상 변화를
비교 분석한 결과 다음과 같은 결론을 도출하였다.

출발물질의 $\mathrm{Ca} / \mathrm{P}$ 몰 비율을 1.602 로 조절하여 $\mathrm{HAp} /$ $\beta-\mathrm{TCP}$ 의 비율이 $60: 40$ 으로 혼재된 $\mathrm{BCP}$ 분말을 합성 하였으며, $\mathrm{HBSS}$ 에 침적 3 주 후 저결정성의 $\mathrm{HAp}$ 가 생 성됨을 확인하였다. $\mathrm{Mg}$ 이온이 치환된 $\mathrm{BCP}$ 분말의 결 정상 분석에서 $\mathrm{HAp}$ 의 (211)면과 $\beta-\mathrm{TCP}$ 의 (0210)면이 나타남을 관찰할 수 있었다. $\mathrm{Mg}$ 이온의 치환 시 $\mathrm{Mg}$ 와 $\mathrm{Ca}$ 의 이온 반경의 차이로 인한 $\beta-\mathrm{TCP}$ 의 (0210)면의 회 절패턴이 이동하는 현상을 관찰 할 수 있다. 또한, 인산 칼슘에 $\mathrm{Mg}$ 이온을 치환할 경우 $\mathrm{Mg}$ 이온 자체의 우수 한 생체활성으로 인하여 HBSS 침적 1주 후부터 저결성 의 $\mathrm{HAp}$ 가 생성됨을 관찰하였다. $\mathrm{Si}$ 이온이 치환된 $\mathrm{BCP}$ 분말의 결정상 분석에서 $\mathrm{HAp}$ 의 (211)면과 $\beta-\mathrm{TCP}$ 의 (0210)면이 나타남을 관찰할 수 있었다. $\mathrm{Si}$ 이온 치환에 따라 원자간 거리 차이로 인하여 회절패턴이 이동하는 현상이 나타났으며, 결정상 분석과 분광 분석에서 $\mathrm{Si}$ 치 환으로 인하여 $\mathrm{SiO}_{4}$ 사면체 구조에서 기인하여 생성되 는 $\mathrm{SiO}_{4}^{4-}$ 이온의 존재로 $\mathrm{BCP}$ 구조적 안정성이 감소됨 을 확인하였다. 이로 인해 HBSS 침적 1 주 후부터 저결 정성 $\mathrm{HAp}$ 가 생성됨을 관찰하였다. 또한, 세포 시험 결 과에서도 $\mathrm{Mg}$ 이온이 치환된 $\mathrm{BCP}$ 분말은 $\mathrm{Mg}$ 이온 자 체의 우수한 생체활성의 결과로, $\mathrm{Si}$ 이온이 치환된 $\mathrm{BCP}$ 분말은 $\mathrm{Si}$ 이온의 치환에 따른 구조적 안정성 감소로 인 하여 $\mathrm{BCP}$ 분말에 비하여 세포 성장률이 우수하였으며, $\mathrm{BCP}$ 분말을 포함하여 금속이온이 치환된 $\mathrm{BCP}$ 분말은 생체재료로서 적용이 가능하리라고 판단되어진다.

\section{감사의 글}

이 논문은 2012년도 정부(교육과학기술부)의 재원으로 한국연구재단의 기초연구사업 지원을 받아 수행된 연구 임(20120002219).

\section{참 고 문 헌}

[1] K. de Groot, "Clinical applications of calcium phosphate biomaterials; A review", Ceram. Int. 19 (1993) 363.

[2] M. Jarcho, "Biological aspects of calcium phosphates: properties and applications", Dent. Clin. North. Am. 30 (1986) 25.

[ 3 ] R.W. Bucholz, A. Carlton and R.E. Holmes, "Hydroxyapatite and tricalcium phosphate bone graft substitutes", Orthop. Clin. North. Am. 18 (1987) 323.

[4] L.L. Hench, "Bioceramics", J. Am. Ceram. Soc. 81 (1998) 1705.

[ 5 ] C.P.A.T. Klein, A.A. Driessen, K. de Groot and A. van den Hooff, "Biodegradation behavior of various cal- 
cium phosphate materials in bone tissue", J. Biomed. Mater. Res. A 17 (1983) 769.

[6] S.V. Dorozhkin and M. Epple, "Biological and medical significance of calcium phosphates", Angew. Chem. Int. Ed. 41 (2002) 3130.

[ 7 ] S. Yamada, D. Heyman, J.K. Bouler and G. Daculsi, "Osteoclastic resorption of calcium phosphate ceramics with different hydroxyapatite/ $\beta$-tricalcium phosphate ratios", Biomaterials 18 (1997) 1037.

[ 8 ] J.M. Bouler, R.Z. LeGeros and G. Daculsi, "Biphasic calcium phosphates: Influence of three synthesis parameters on the HA/ $\beta$-TCP ratio", J. Biomed. Mater. Res. A 51 (2000) 680.

[9] M. Jarcho, "Calcium phosphate ceramics as hard tissue prosthetic", Clin. Orthop. Relat. Res. 157 (1981) 259.

[10] S.G. Dahl, P. Allain, P.J. Marie, Y. Mauras, G. Boivin, P. Ammann, Y. Tsouderos, P.D. Delmas and C. Christiansen, "Incorporation and distribution of strontium in bone", Bone 28 (2001) 446.

[11] R.S. Lee, M.V. Kayser and S.Y. Ali, "Calcium phosphate microcrystal deposition in the human intervertebral disc", J. Anat. 208 (2006) 13.

[12] N.C. Blumenthal, F. Betts and A.S. Posner, "Precipitation of calcium phosphates from electrolyte solutions III. Radiometric studies of the kinetics of precipitation and aging of calcium phosphates", Calcif. Tissue. Int. 18 (1975) 81.

[13] A. Bigi, G. Cojazzi, S. Panzavolta, A. Ripamonti, N. Roveri, M. Romanello, K. Noris Suarez and L. Moro, "Chemical and structural characterization of the mineral phase from cortical and trabecular bone", J. Inorg. Biochem. 68 (1997) 45.

[14] R.Z. Le Geros, "Calcium phosphates in oral biology and medicine", Monogr. Oral. Sci. 15 (1991) 1.

[15] I.R. Gibson, S.M. Best and W. Bonfield, "Chemical characterization of silicon-substituted hydroxyapatite", J. Biomed. Mater. Res. A. 44 (1999) 422.

[16] K.J. Lilley, U. Gbureck, J.C. Knowles, D.F. Farrar and J.E. Barralet, "Cement from magnesium substituted hydroxyapatite”, J. Mater. Sci. Mater. Med. 16 (2005) 455.

[17] W.L. Suchanek, K. Byrappa, P. Shuk, R.E. Riman, V.F. Janas and K.S. TenHuisen, "Effect of sintered silicatesubstituted hydroxyapatite on remodelling processes at the bone-implant interface", Biomaterilas 25 (2004) 4647.

[18] J. Pena and M. Vallet-Regi, "Hydroxyapatite, tricalcium phosphate and biphasic materials prepared by a liquid mix technique", J. Euro. Ceram. Soc. 23 (2003) 1687.

[19] S.R. Kim, J.H. Lee, Y.T. Kim, D.H. Riu, S.J. Jung, Y.J. Lee, S.C. Chung and Y.H. Kim, "Synthesis of Si, Mg substituted hydroxyapatites and their sintering behaviors", Biomaterials 24 (2003) 1389.
[20] O. Gauthier, J.M. Bouler, E. Aguado, P. Pilet and G. Daculsi, "Macroporous biphasic calcium phosphate ceramics: influence of macropore diameter and macroporosity percentage on bone ingrowth", Biomaterials 19 (1998) 133.

[21] R.Z. Le Geros, "Calcium phosphates in oral biology and medicine, in: H.M. Myers (Ed.)", Monographs in Oral Science Karger Basel 31 (1991).

[22] M. Palard, E. Champion and S. Foucaud, "Synthesis of silicated hydroxyapatite $\mathrm{Ca}_{10}\left(\mathrm{PO}_{4}\right)_{6-\mathrm{x}}\left(\mathrm{SiO}_{4}\right)_{\mathrm{x}}(\mathrm{OH})_{2-\mathrm{x}}$ ", J. Solid State Chem. 181 (2008) 1950.

[23] Th. Leventouri, C.E. Bunaciu and V. Perdikatsis, "Neutron powder diffraction studies of silicon-substituted hydroxyapatite", Biomaterials 24 (2003) 4205.

[24] A. Mortier, J. Lemaitre and P.G. Rouxhet, "Temperatureprogrammed characterization of synthetic calcium-deficient phosphate apatites", Thermochimica Act 143 (1989) 265.

[25] S. Gomes, G. Renaudin, A. Mesbah, E. Jallot, C. Bonhomme, F. Babonneau and J.-M. Nedelec, "Thorough analysis of silicon substitution in biphasic calcium phosphate bioceramics: A multi-technique study", Acta Biomateralia 6 (2010) 3264.

[26] T.W. Kim, D.H. Kim, H.H. Jin, H.S Lee, H.C. Park and S.Y. Yoon, "Bioactivity behavior of $\mathrm{Si}$ and $\mathrm{Mg}$ ion-substituted biphasic calcium phosphate powders", J. Kor. Cry. Grow. Cry. Tech. 22 (2012) 92.

[27] S. Kannan, I.A.F. Lemos, J.H.G. Rocha and J.M.F. Ferreira, "Synthesis and characterization of magnesium substituted biphasic mixtures of controlled hydroxyapatite/ $\beta$-tricalcium phosphate ratios", J. Solid. State. Chem. 178 (2005) 3190.

[28] L.H. Long, L.D. Chen, S.Q. Bai, J. Chang and K.L. Lin, "Preparation of dense $\beta-\mathrm{CaSiO}_{3}$ ceramic with high mechanical strength and HAp formation ability in simulated body fluid", J. Eur. Ceram. Soc. 26 (2006) 1701.

[29] C.W. Song, T.W. Kim, D.H. Kim, H.H. Jin, K.H. Hwang, J.K. Lee, H.C. Park and S.Y. Yoon, "In situ synthesis of silicon-substituted biphasic calcium phosphate and their performance in vitro", J. Phys. Chem. Solid. 73 (2012) 39.

[30] K.S. TenHuisen and P.W. Brown, "Effects of magnesium on the formation of calcium-deficient hydroxyapatite from $\mathrm{CaHPO}_{4} \cdot 2 \mathrm{H}_{2} \mathrm{O}$ and $\mathrm{Ca}_{4}\left(\mathrm{PO}_{4}\right)_{2} \mathrm{O}$, J. Biomed. Mater. Res. 36 (1997) 306.

[31] X. Lu and Y. Leng, "Theoretical analysis of calcium phosphate precipitation in simulated body fluid", Biomaterials 26 (2005) 1097.

[32] T.W. Kim, D.H. Kim, H.H. Jin, H.S Lee, H.C. Park and S.Y. Yoon, "Bioactivity behavior of biphasic calcium phosphate powders prepared by co-precipitation method", J. Kor. Cry. Grow. Cry. Tech. 22 (2012) 99. 